PATRYCJA E. HEROD* - WARSZAWA

Postanowienia wspomnianej kodyfikacji okazały się wyjątkowo trwałe i dlatego byta ona podstawowym oraz wzorcowym dla innych biskupów zbiorem ustaw Kościoła płockiego aż do czasów reformy trydenckiej. Leszek Zygner ${ }^{1}$

\title{
USTAWODAWSTWO KARNE W KODYFIKACJI PLOCKIEJ BISKUPA JAKUBA Z KORZKWI (1396-1425)
}

\section{1. Żywot czlowieka niepospolitego}

Autorem jednego z najciekawszych pomników średniowiecznego ustawodawstwa kościelnego w Polsce był człowiek nietuzinkowy, który przez całe życie starał się znajdować w centrum wydarzeń zarówno kształtujących losy własnego narodu, jak i współczesne oblicze Świętej Matki Kościoła na starym kontynencie. Mowa tu o jednym z najwybitniejszych przedstawicieli polskiego episkopatu na przestrzeni XIV i XV wieku - Jakubie z Korzkwi herbu Syrokomla. Przyszły doktor dekretów, audytor Roty Rzymskiej, biskup płocki, prawnik i prawodawca, wreszcie zaufany dyplomata Władysława Jagiełły, który poruczał mu zadania najcięższego kalibru stojące na straży dobra państwa, przyszedł na świat około 1350 roku, co udało się ustalić dzięki dokumentom zachowanym z procesu polskokrzyżackiego z roku 1422, na którym blisko siedemdziesięcioletni biskup był świadkiem strony polskiej. Według starszej historiografii, ${ }^{2}$ która bez wątpienia

* Patrycja Ewa Herod - mgr prawa i mgr historii, doktorantka w Instytucie Historii UKSW w Warszawie.

${ }^{1}$ L. Zygner, Wyksztatcenie, uniwersyteckie biskupów płockich $w$ wiekach XIV-XV, „, Roczniki Historyczne", 65 (1999) s. 86.

${ }^{2}$ M.in. Krzyżanowski W., Katedra płocka i jej biskupi, Płock 1877, s. 99, Nowak Z., Dyplomacja polska w czasach Jadwigi i Władystawa Jagietty (1382-1434), w: Historia dyplomacji polskiej, t. 1, red. M. Biskup, Warszawa 1980, s. 368. 
opierała się na przekazie Jana Długosza, ${ }^{3}$ upatrywano w Jakubie absolwenta uniwersytetu w Bolonii ${ }^{4}$, najstarszego uniwersytetu w zachodnim świecie, założonego już w 1088 roku, i będącego swoistym modelem dla innych średniowiecznych szkół wyższych. Jednak obecnie cześć historyków ${ }^{5}$ skłania się ku studiom odbytym przez przyszłego doktora dekretów na uniwersytecie w Rzymie, utworzonym 20 kwietnia 1303 roku przez papieża Bonifacego VIII . Promocja doktorska Jakuba z Korzkwi miała miejsce na pewno przed 11 stycznia 1385 roku, a założyć można, że mogło już do niej dojść nawet przed 24 października 1383 roku. Przyszły audytor Roty Rzymskiej trafił na dwór papieski przed 11 stycznia 1385 roku, o czym świadczą zachowane źródła. ${ }^{7}$ Jakub z Korzkwi, po złożeniu specjalnych egzaminów przed wicekanclerzem kardynałem Franciszkiem Moricottim ${ }^{8}$, został 23 lutego 1386 roku uroczyście powołany na stanowisko audytora Roty Rzymskiej, a 26 lutego objął poruczone mu obowiązki jako pierwszy Polak piastujący tak nobilitujący urząd. ${ }^{9}$ Do zakresu obowiązków Jakuba z Korzkwi jako audytora Roty Rzymskiej należały głównie sprawy beneficjalne dotyczące metropolii gnieźnieńskiej i praskiej, co w żaden sposób dziwić nie może z uwagi na jego przynależność narodową, choć zdarzały się też sprawy leżące w jego jurysdykcji $\mathrm{z}$ diecezji niemieckich, chociażby diecezji merseburskiej.

Dnia 27 lipca 1396 roku w Wiecznym Mieście zmarł Maffiolus Lampugnani z Mediolanu, arcybiskup Raguzy (1385), arcybiskup Messyny (1387), biskup płocki od 1392 roku. Z uwagi na to, iż Maffiolus zmarł w Rzymie, Bonifacy IX ${ }^{10}$, korzystając z prawa nominacji, na jego następcę wyznaczył 31 lipca 1396 roku Jakuba z Korzkwi, który przez dziesięć lat pracy jako audytor Sacra Romana Rota pogłębił jakże istotne zdolności dyplomatyczne, nabył bezcennego doświadczenia prawniczego, oraz ciesząc się rozległymi znajomościami nie tylko na dworze papieskim, stał się jedną z najbardziej wpływowych osób na firmamencie polskiego duchowieństwa przełomu wieków XIV i XV.

Jakub z Korzkwi przybywając do ojczystego kraju i osiadając na biskupim tronie w Płocku postrzegany był, notabene zgodnie z prawdą, jako osoba niezwykle wykształcona oraz obyta $\mathrm{w}$ świecie. $\mathrm{Z}$ jego przymiotów doskonale zdawał sobie sprawę król Władysław Jagiełło i często angażował go do delikatnej i jakże

${ }^{3}$ J. Długosz, Vitae episcoporum plocensium, w: Pomniki dziejowe Polski, t. 6, Warszawa 1961, s. 610 .

${ }^{4}$ Miasto w północnych Włoszech położone między rzeką Pad a Apeninami.

${ }^{5}$ M.in. Bazydło J., Jakub z Korzkwi, w: Encyklopedia katolicka, t. 7, red. S. Wielgus, Lublin 1997, s. 720, Swieżawski A., Jakub z Korzkwi herbu Syrokomla (ur. przed 1350-1425), w: Polski Słownik Biograficzny, t. 10, red. K. Lepszy, Warszawa 1962, s. 358, Żebrowski T., Zarys dziejów diecezji płockiej, Płock 1976, s. 48.

${ }^{6}$ Benedetto Gaetani (ok. 1235-1303), papież od 24 XII 1294 r.

${ }^{7}$ A. Vetulani, Średniowieczne rękopisy płockiej biblioteki katedralnej, „,Roczniki Biblioteczne”, 7 (1963) s. 360.

${ }^{8}$ Francesco Moricotti Prignano (zm. 1394), włoski kardynał tytułu św. Euzebiusza, bratanek Urbana VI, gubernator Kampanii (1380) i Fondi (1381), wicekanclerz Św. Kościoła Rzymskiego. Przewodniczył konklawe w 1389 r. i konsekrował nowego papieża Bonifacego IX.

${ }^{9}$ Vetulani, Średniowieczne rękopisy, s. 360 i 425.

${ }^{10}$ Pietro Tomacelli (ok. 1350-1404), papież obediencji rzymskiej od 1389 r. 
istotnej służby pro publico bono. Warte odnotowania jest, że były audytor Roty Rzymskiej zasilił grono posłów wyznaczonych na sobór w Konstancji 6 października 1414 roku. ${ }^{11}$ Oprócz Jakuba z Korzkwi, do godnego reprezentowania Polski na arenie międzynarodowej powołani zostali: arcybiskup Mikołaj Trąba ${ }^{12}$, biskup włocławski Jan ${ }^{13}$, elekt poznański Łaskarz ${ }^{14}$ oraz rycerze - kasztelan kaliski Janusz z Tuliszkowa ${ }^{15}$ i znany w całej Europie Zawisza Czarny z Garbowa ${ }^{16}$. Biskup płocki wraz $\mathrm{z}$ biskupem pistojańskim ${ }^{17}$, waureńskim ${ }^{18}$ oraz salisburskim ${ }^{19}$ został wyznaczony przez ojców soborowych do wysłuchiwania spraw oraz skarg kierowanych do soboru bez prawa załatwiania ich w formie wyroku. ${ }^{20}$ Jednakże już 17 sierpnia 1415 roku udzielono im pełnej władzy również w zakresie uprawnień do prowadzenia tych postępowań do końca, wraz z ich definitywnym zamykaniem. Rzecz jasna, sprawy te prowadzone musiały być w sposób uproszczony, bez upodabniania do sądu. Spod jurysdykcji Jakuba były wyłączone sprawy kościołów katedralnych oraz kwestie na tyle istotne, że było nie do pomyślenia, aby mogły o nich decydować jedynie cztery osoby spośród ojców soborowych. Bez wątpienia należy zauważyć, że na fakt poruczenia Polakowi tak odpowiedzialnego stanowiska miała wpływ jego wcześniejsza, aż dziesięcioletnia, praca jako audytora Roty Rzymskiej.

Z końcem XIV wieku w skład diecezji płockiej poza północnym Mazowszem wchodziła ziemia dobrzyńska wraz z niewielką ziemią michałowską, a na wscho-

${ }^{11}$ J. Długosz, Roczniki, czyli kroniki sławnego Królestwa Polskiego, ks. XI, Warszawa 2009, s. 42.

${ }^{12}$ Mikołaj Trąba herbu Trąby (ok. 1358-1422), notariusz królewski od 1390 r., podkanclerzy koronny 1403-1412, arcybiskup halicki 1410-1412, arcybiskup gnieźnieński od 1412 r., pierwszy prymas Polski od $1417 \mathrm{r}$.

${ }^{13}$ Jan Kropidło (1360/64-1421), w latach 1382-96 książę strzelecki, od 1396 r. książę opolski, w latach 1382-84 biskup poznański, 1384-89 biskup włocławski, 1389-1394 nominat (urzędu nie objął) arcybiskup gnieźnieński, 1394-98 biskup kamieński, 1398-1402 biskup chełmiński, od 1402 r. ponownie biskup włocławski.

${ }^{14}$ Andrzej Laskarz (Laskarys) z Gocławic herbu Godziemba (1362-1426), biskup poznański od 1414 r., dyplomata, doktor praw, uczestnik soborów, zwolennik koncyliaryzmu.

${ }^{15}$ Janusz z Tuliszkowa herbu Dryja, kasztelan kaliski od 1403 r., od 1410 r. starosta królewski w Gdańsku do czasu wycofania się wojsk polskich. W latach 1414-1418 delegat strony polskiej na sobór w Konstancji. Prawdopodobnie w 1416 r. został członkiem Zakonu Kolii Sabaudzkiej. W 1417 r. lub 1418 r. przystąpił do Bractwa św. Krzysztofa. Najprawdopodobniej ostatnią podróż dyplomatyczną odbył do Austrii w $1424 \mathrm{r}$.

${ }^{16}$ Zawisza Czarny z Garbowa herbu Sulima (ok. 1370-1428), jeden z najsłynniejszych polskich rycerzy, niepokonany w licznych turniejach, symbol cnót rycerskich, starosta kruszwicki od roku 1417, starosta spiski od 1420 r. Wielokrotnie posłował na dwór Zygmunta Luksemburskiego i właśnie osłaniając jego odwrót z pola walki pod Gołąbcem w 1428 r. poniósł śmierć.

${ }^{17}$ Mateusz Diamanti, biskup Pistoi od 1400 r. do śmierci 12 XII 1425 r.

${ }^{18}$ Jan Belli[n], biskup Lavaur (Vaurum) od 1415 r. do śmierci 21 września 1433 r.

${ }^{19}$ Robert Hallum, biskup Salisbury od 1417 r. do śmierci na Soborze w Konstancji 4 IX 1417 r.

${ }^{20}$ A. Baron, H. Pietras, Dokumenty soborów powszechnych, t. 3, Kraków 2004, s. 145. 
dzie jej granice były równoznaczne z zasięgiem władzy książąt mazowieckich. ${ }^{21}$ $Z$ racji swojego niekorzystnego usytuowania biskupstwo płockie należało do grona tych trudniejszych w zarządzaniu i przed nowo obranym na duszpasterza tej diecezji Jakubem z Korzkwi stało nie lada wyzwanie. Już niemalże na samym wstępie objęcia rządów, bo w roku 1401, były audytor Roty porozumiał się w sprawie dziesięcin $\mathrm{z}$ terenów podlegających zakonowi z wielkim mistrzem Konradem von Jungingenem ${ }^{22}$, który potwierdził umowę biskupa ze szlachtą z ziemi dobrzyńskiej dotyczącą tej ważkiej kwestii. Tym samym zwierzchnik państwa zakonnego potwierdził władzę administracyjną biskupów płockich na okupowanym przez Krzyżaków terytorium. W lipcu 1410 roku wojska polskie na czele z królem Władysławem Jagiełłą przeprawiały się pod Czerwińskiem ${ }^{23}$ przez Wisłę, by połączyć się z wojskami litewskimi i ruszyć na państwo zakonne. Jakub z Korzkwi, jako hierarcha i duszpasterz diecezji, po uroczystej mszy 2 lipca 1410 roku w tutejszym klasztorze wygłosił do całego wojska kazanie po polsku, ${ }^{24}$ rozprawiając na temat wojny sprawiedliwejej i niesprawiedliwej. W ujęciu znakomitego pol-

${ }^{21}$ K. Pacuski, Rozwój sieci parafialnej diecezji płockiej w XI-XVI w., „Studia Płockie”, 3 (1975) s. 59.

${ }^{22}$ Konrad von Jungingen (ok. 1355-1407), wielki mistrz zakonu krzyżackiego od 1393 r. Dzięki swojej zręcznej polityce uzyskał Żmudź, a w 1402 r. zakupił od Brandenburgii Nową Marchię, która przyniosła jednak więcej szkód niż korzyści z powodu ciągłych buntów miejscowego rycerstwa. W polityce bałtyckiej zmuszony był stanąc do konkurencji z nowo powstałą unią kalmarską. Konflikt interesów, którego przyczyną było opanowanie przez Krzyżaków w 1398 r. Gotlandii, spowodował długoletnie napięte stosunki z Danią, Szwecją i Norwegią. Zagrożenie wojną ze wszystkich stron zmusiło von Jungingena do szukania porozumienia $z$ jednym $z$ rywali. W tej sytuacji zdecydował się na gesty życzliwości w stosunkach z Władysławem Jagiełłą. Według Kroniki Gdańskiej, umierający wielki mistrz ostrzegać miał dostojników krzyżackich przed wyborem swego wojowniczego brata na następcę, nazywając go głupcem.

${ }^{23}$ Wieś nad Wisłą położona w województwie mazowieckim. Historia Czerwińska przez stulecia nierozerwalnie była związana $\mathrm{z}$ historią tutejszego klasztoru kanoników regularnych, powstałego w XII w. Pierwszy dokument wspominający o Czerwińsku, pochodzący z 1155 r., to bulla papieża Hadriana IV dotycząca właśnie klasztoru. Nie tylko jednak związek z klasztorem powodował rozkwit miejscowości. Położona nad Wisłą, stanowiła ważny punkt na szlaku handlowym łączącym Pomorze z Mazowszem. Była też ważnym punktem obronnym podczas najazdów pruskich, jaćwięskich i litewskich. W lipcu 1410 r. wojska polskie pod przewodnictwem Jagiełły przeprawiły się pod Czerwińskiem przez Wisłę, by połączyć się z wojskami litewskimi i ruszyć na państwo zakonne.

${ }^{24}$ Według Kozłowskiego, niektórzy uważają, że przedmiotowe kazanie miał wygłosić biskup Jakub w Płocku, przez który Jagiełło szedł do Jeżewa przy granicy pruskiej i, pod którym wojsko stanęło obozem, a w Czerwińsku miało miejsce zwyczajne kazanie podczas uroczystości (F. Kozłowski, Dzieje Mazowsza za panowania książąt, Warszawa 1858, s. 200).

${ }^{25}$ Stanisław ze Skarbimierza (zm. 1431 r.) i Paweł Włodkowic omawiali problematykę wojny sprawiedliwej. Pierwszy z nich stwierdził, że wojna jest dopuszczalna w obronie własnej, ojczyzny i odzyskania niepodległości, a władca katolicki może posłużyć się nawet pomocą niewiernych w walce przeciw złym chrześcijanom, tj. takim, którzy prowadzą wojnę niesprawiedliwą. Natomiast Paweł Włodkowic uznawał równość wszystkich ludzi względem natury i ich wolną wolę, a także uważał, że nie jest dozwolone zmuszać niewiernych bronią lub uciskami do wiary chrześcijańskiej. Zabieranie zaś przez papieży i cesarza ziem niewiernych jest wbrew prawu natury i boskiemu, gdyż władza ich była także tym prawom podporządkowana 
skiego kronikarza, biskup płocki ,jako człowiek niezwykle wykształcony oraz mający dar wymowy, wieloma jasnymi dowodami wykazał, że wojna podjęta przez króla z Krzyżakami jest jak najbardziej słuszna. Dziwnym darem przekonywania zapalił serca wszystkich słuchających rycerzy do obrony Królestwa i ojczyzny i podjęcia mężnie walki z wrogiem" ${ }^{26}$. Oratorski popis byłego audytora Sacra Romana Rota zachęcił do wytrwania i męstwa w boju przeciwko nieprzyjaciołom ojczyzny.

Objęcie przez Jakuba z Korzkwi nadanego mu biskupstwa, zbiegło się z okresem kojącej stabilizacji na Mazowszu po wyniszczających najazdach i klęskach XIII i XIV wieku. Trzema najpotężniejszymi instytucjami Mazowsza płockiego były: kapituła katedralna płocka, biskup oraz książęta mazowieccy. Stosunki między nimi miały decydujące znaczenie także dla zarządzania diecezją płocką i stanowiły niejako warunek jej reformy na wszystkich płaszczyznach, o jakich myślał Jakub.

Biskup płocki, jako przedsiębiorczy administrator, w zarządzaniu powierzoną mu diecezją kładł duży nacisk na zapewnienie jej instytucjom kościelnym możliwie najlepszych podstaw ekonomicznych. Do 1403 roku erygował przynajmniej dziesięć parafii. ${ }^{27}$ Warto zwrócić uwagę, że obok znakomitych posunięć administracyjnych byłego audytora Roty widoczny jest brak troski z jego strony o zapewnienie właściwego życia religijnego kleru i wiernych. Próżno szukać wskazań ściślej pastoralnych i duszpasterskich, dotyczących chociażby kazań, wykształcenia, wychowania czy szkoły ${ }^{28}$.

Jakub z Korzkwi do śmierci prowadził niezwykle aktywną działalność kościelną. Był obecny na synodzie prowincjonalnym w Wieluniu ${ }^{29} \mathrm{~W} 1420$ roku. $^{30}$ W lipcu tego samego roku w Łęczycy ${ }^{31}$ uczestniczył w sądzie nad kanclerzem biskupem krakowskim Wojciechem Jastrzębcem. ${ }^{32} \mathrm{~W} 1422$ roku brał udział w synodzie w Łęczycy. ${ }^{33}$ Jeszcze 1 maja 1425 roku w Brześciu Kujawskim ${ }^{34}$ był świadkiem nadania przez Władysława Jagiełłę przywilejów dla stanów w związku z obietnicą wyboru po jego śmierci syna Władysława na króla Polski. ${ }^{35}$ Natomiast 27 maja 1425 roku, ${ }^{36}$ po 29 latach rządów biskupich w diecezji płockiej, Jakub zKorzkwi herbu Syrokomla przeniósł się do wieczności.

${ }^{26}$ J. Długosz, Roczniki, czyli kroniki sławnego Królestwa Polskiego, ks. X-XI, Warszawa 2009, s. 76.

${ }^{27}$ Żebrowski, Zarys, s. 49.

${ }^{28}$ J. Kłoczowski, Biskup Jakub z Korzkwi (1396-1425) i próba restauracji Kościoła płockiego, „Studia Płockie”, 3 (1975) s. 113.

${ }^{29}$ Miasto w województwie łódzkim. Pierwsze wzmianki o osadzie pochodzą z 2. poł. XIII w. Przypuszcza się, że prawa miejskie Wieluń uzyskał ok. 1282 r.

${ }^{30}$ L. Zygner, Kultura historyczna przedstawicieli Kościoła płockiego w świetle ich zeznań na procesie polsko-krzyżackim w latach 1422-1423, „Notatki Płockie”,1 (1994) s. 4.

${ }^{31}$ Miasto w województwie łódzkim. Prawa miejskie otrzymała Łęczyca przed $1267 \mathrm{r}$.

${ }^{32}$ Żebrowski, Zarys, 49.

${ }^{33}$ Swieżawski, Jakub, s. 358.

${ }^{34}$ Miasto położone na terenie województwa kujawsko-pomorskiego, dawna siedziba książąt kujawskich.

${ }^{35}$ Żebrowski, Zarys, s. 49.

${ }^{36}$ Długosz, Roczniki, ks. XI, s. 223. 


\subsection{Synody diecezjalne do 1425 roku oraz układ statutów plockich}

Pierwszym synodem diecezjalnym, którego akta przetrwały zawieruchy dziejowe, aby dawać świadectwo następnym pokoleniom był synod odbyty w środkowej Francji, a dokładniej w Auxčrre nad rzeką Yonne, ${ }^{37}$ pomiędzy 585 a 606 rokiem. ${ }^{38}$ Jednakże zwyczaj zwoływania synodów diecezjalnych sięga bezsprzecznie samych początków chrześcijaństwa. Obok duchowieństwa swoją obecnością często zaszczycali je również co znamienitsi świeccy. Głównym celem zwoływania synodów diecezjalnych było zapoznanie ogółu duchowieństwa i wiernych z ideą oraz normami powszechnego prawa kościelnego. Już reorganizator Sacra Romana Rota, Innocenty III, pragnął, aby synod diecezjalny stanowił środek do realizowania postanowień synodu prowincjonalnego, który z kolei były nośnikiem dla dekretałów papieskich i praktycznie jedyną drogą do dotarcia rozporządzeń następcy św. Piotra do świadomości biskupa ${ }^{39}$ Rządcy powierzanych im biskupstw na synodach poruszali sprawy wewnątrzdiecezjalne, w efekcie czego niejednokrotnie kler był zobowiązany do świadczeń na rzecz Kościoła lub na pokrycie nadzwyczajnych wydatków biskupiego stołu. Oprócz spraw czysto administracyjnych duszpasterze diecezji chcieli na forum synodalnym reformować obyczaje zarówno duchownych, jak i świeckich zamieszkujących podległe im biskupstwa. Niebagatelną rolę odgrywała tu również kwestia karności, a co za tym idzie przestrzegania prawa kościelnego. Obrady gremium synodalnego trwały średnio dwa-trzy dni i zazwyczaj wieńczyło je uchwalenie, a następnie ogłoszenie przez biskupa, prawa diecezjalnego w postaci tzw. statutów synodalnych. ${ }^{40}$

Nie inaczej przedstawiała się sytuacja w biskupstwie płockim, które zostało erygowane około 1075 roku, po tym kiedy legaci papiescy przywieźli Bolesławowi Śmiałemu list od papieża Grzegorza VII ${ }^{41}$, datowany na 20 kwietnia 1075 roku. Po zarzutach głowy Kościoła dotyczących małej liczby biskupów przy zbyt rozległych diecezjach, z zasięgu archidiecezji gnieźnieńskiej wydzielono biskupstwo płockie, które przeznaczone było dla całego Mazowsza. Należy pamiętać, iż za czasów Jakuba z Korzkwi biskupstwo płockie było stołeczną diecezją politycznie samodzielnego księstwa mazowieckiego, co stawiało je wyżej od wielu innych biskupstw polskich. ${ }^{42}$

Pierwsze wyraźne wzmianki o synodzie odbytym w diecezji płockiej odnoszą się do roku 1216, gdy biskup Gedko ${ }^{43}$ odprawił synod przy udziale arcybiskupa

\footnotetext{
${ }^{37}$ Lewy dopływ Sekwany.

${ }^{38}$ W. Góralski, Synody płockie - historia i współczesność, „Notatki Płockie”, 146 (1991) s. 23.

${ }^{39}$ Tenże, Z przeszłości synodalnej diecezji płockiej, „Studia Płockie”, 13 (1985) s. 114.

${ }^{40}$ Góralski, Synody plockie, s. 21.

${ }^{41}$ Hildebrand (ok. 1015-1085), święty Kościoła katolickiego, papież od 1073 r., reformator, spierał się z Henrykiem IV o inwestyturę.

${ }^{42}$ A. Vetulani, Średniowieczny biskupi Płock jako ośrodek kultury umysłowej, „Miesięcznik Pasterski Płocki”, 11 (1974) s. 428.

${ }^{43}$ Gedko I (ok. 1160-1223), biskup płocki od 1206 r. Przez część kapituły krakowskiej został wybrany na biskupa krakowskiego w 1207 r. obok mistrza Wincentego, jednakże papież na stolicę biskupią zatwierdził jego konkurenta. W 1222 r. odstąpił biskupowi pruskiemu Chrystianowi jurys-
} 
Henryka Kietlicza ${ }^{44}$ jako legata papieskiego. ${ }^{45}$ Wiemy o tym $\mathrm{z}$ listu papieża Honoriusza $\mathrm{III}^{46}$ do naszego arcybiskupa z 16 czerwca 1218 roku ${ }^{47}$ Dowiadujemy się $\mathrm{z}$ niego, że przed tą datą pod osobistym przewodnictwem metropolity odbył się synod w Płocku. Nie było to niczym nadzwyczajnym, ponieważ Kietlicz wiosną 1216 roku, po swoim powrocie z soboru laterańskiego IV, zwołał synod prowincjonalny, po którym zwoływał po diecezjach synody reformistyczne w duchu odnowy zapoczątkowanej na niedawno zakończonym soborze powszechnym. ${ }^{48} \mathrm{Nie}-$ stety nie dysponujemy żadnymi aktami z tego wydarzenia. Dobitnie trzeba zaznaczyć, iż nie znamy dokładnej daty pierwszego poświadczonego źródłowo synodu diecezjalnego odbytego w Płocku, ale biorąc powyższe pod uwagę należy przyjąć, że musiał się on odbyć pomiędzy wiosną 1216 a początkiem 1218 roku.

Niewątpliwie w wiekach XIII i XIV odbywały się w biskupstwie płockim synody, na których przyjmowano uchwały synodów prowincjonalnych, ale brak o nich jakiejkolwiek wzmianki, a ich statuty zaginęły. ${ }^{49} \mathrm{~W}$ przedmowie do swej kodyfikacji statutów diecezjalnych ogłoszonej w 1423 roku Jakub z Korzkwi wspomina o konstytucjach wydanych przez swoich poprzedników, które wznawia i potwierdza na synodzie diecezjalnym odprawionym w Płocku 8 września 1398 roku. ${ }^{50}$ Również w kilku tekstach wchodzących w skład tej kodyfikacji biskup ustawodawca powołuje się na postanowienia swoich poprzedników i na dawniejsze statuty synodalne. Dla przykładu należy podać niektóre z nich. W artykule $D e$ constitucionibus (1) biskup nakazuje przestrzeganie porządku nabożeństw ustanowionego przez jego poprzedników i wpisanego do księgi katedry płockiej. ${ }^{51}$ Notabene, takie zarządzenia były wydawane na synodach diecezjalnych i miały charakter statutów synodalnych. W artykule De secretis capituli non revelandis (7) znajduje się postanowienie, iż tylko ten może być dopuszczony do pełnienia

dykcję kościelną w ziemi chełmińskiej i lubawskiej. Ponadto odstąpił również dziesięciny i majątki należące do biskupstwa płockiego na tym terenie. Nadanie to służyło jako udostępnienie terenu pod bazę dla akcji misyjnej w Prusach.

${ }^{44}$ Henryk Kietlicz (ok. 1150-1219), arcybiskup gnieźnieński od 1199 r. Po powrocie z soboru laterańskiego IV przedstawił program reformy kościelnej, która zawierała cztery postulaty: wprowadzenie celibatu duchowieństwa świeckiego zarówno wyższego, jak i niższego, uwolnienie kościoła spod władzy świeckiej (nadanie immunitetu), wyłączenie duchownych spod kompetencji sądów świeckich oraz zaprowadzenie kapitulnego wyboru biskupów. Sukces reformy, pomimo oporu znacznej części duchowieństwa polskiego, arcybiskup zawdzięczał głównie poparciu ze strony papieża Innocentego III, który w razie potrzeby wystawiał odpowiednie bulle nakazujące wprowadzenie poszczególnych postulatów w życie.

${ }^{45}$ Żebrowski, Zarys, s. 77.

${ }^{46}$ Cencio zwany Camerario (ok. 1150-1227), papież od 1216 r. W 1217 r. wydał istotny przywilej dla Krzyżaków, rozciągając na nich przywileje i odpusty, którymi cieszyli się templariusze i joannici.

${ }^{47}$ J. Sawicki, Conciliae. Źródta i studia krytyczne, t. 6: Synody diecezji płockiej i ich statuty, Warszawa 1951, s. 8.

${ }^{48}$ Sawicki, Conciliae, s. 9.

${ }^{49}$ Żebrowski, Zarys, s. 77.

${ }^{50}$ Sawicki, Conciliae, s. 10.

${ }^{51}$ Tamże, s. 11. 
funkcji kanonika katedry płockiej, kto złoży uprzednio przysięgę przed biskupem, względnie dziekanem kapituły oraz, że tak jak było to zarządzone przez jego poprzedników, będzie przestrzegał tajemnicy statutów i sekretów kościoła płockiego.$^{52}$ Natomiast w artykule De sepultaris (27) ustawodawca powołuje się na kilka źródeł, w których są zawarte zakazy udzielania chrześcijańskiego pogrzebu. ${ }^{53}$ Jednym z podnoszonych w tym przepisie aktów tego typu są statutum synodale, które w całej kodyfikacji płockiej oraz w innych aktach wychodzących z kancelarii Jakuba są używane wyłącznie na określenie statutów diecezjalnych. ${ }^{54}$ Przytoczone artykuły wskazują bezsprzecznie, iż pomiędzy synodami, którym przewodził były audytor Roty Rzymskiej, a tym z około 1216 roku również odbywały się zgromadzenia, na których były wydawane statuty. Można jedynie wyrazić głęboki żal, iż żaden z tych statutów nie dotrwał do naszych czasów.

Dopiero za czasów Jakuba z Korzkwi mamy poświadczonych źródłowo kilka synodów. Pierwszy, któremu przewodził świeżo upieczony biskup, odbył się w Płocku 8 września 1398 roku. Uczestniczyła w nim płocka kapituła katedralna, opaci dwóch najbogatszych klasztorów diecezji, (Florian - opat kanoników regularnych w Czerwińsku ${ }^{55}$ oraz Jan - opat benedyktynów na zamku płockim ${ }^{56}$ ), inni dostojnicy świeccy i zakonni, rządcy kościołów parafialnych oraz reszta duchowieństwa diecezjalnego. ${ }^{57}$ Jest to jedyna data synodu odbytego za czasów sprawowania rządów przez Jakuba, co do której nie można mieć wątpliwości, ponieważ została podana $\mathrm{w}$ wydanych wówczas statutach ${ }^{58}$ jakie znajdują się $\mathrm{w}$ interesującej nas szczególnie kodyfikacji prawa diecezjalnego diecezji płockiej, ogłoszonej w Płocku 26 stycznia 1423 roku.

Kolejny synod odbył się najprawdopodobniej 8 listopada 1400 roku. Założyć tak można po przeprowadzeniu analizy okólnika wchodzącego w skład tzw. formularza płockiego, pochodzącego w dużej mierze z czasów Jakuba z Korzkwi. $\mathrm{W}$ treści podnoszonego zarządzenia biskup wzywa duchowieństwo na synod diecezjalny na poniedziałek 8 listopada, niestety bez podania daty rocznej. Wskazana data dzienna za czasów Jakuba wypadała jedynie w roku 1400, 1406, 1417 oraz

${ }^{52}$ Tamże, s. 12.

53 Tamże, s. 12.

${ }^{54}$ Tamże, s. 12-13.

${ }^{55}$ Kanonicy regularni zostali sprowadzeni do Czerwińska ok. 1130 r. przez biskupa płockiego Aleksandra, który zarządzał powierzoną sobie diecezją w latach 1129-56.

${ }^{56}$ Zarówno data ufundowania, jak i osoba fundatora opactwa pozostają nieustaleni. Bez wątpienia opactwo ufundował książę i do niego należało prawo patronatu. On też wyznaczył benedyktynom działkę w obrębie grodu pod klasztor. Fundator musiał władać Mazowszem skoro w tej dzielnicy klasztor uzyskał uposażenie. Nie mogło to nastąpić w czasach Bolesława Śmiałego, gdyż $\mathrm{w}$ tym czasie świadczenia $\mathrm{z}$ grodów mazowieckich należały do benedyktynów z Mogilna. Wezwanie wskazuje na fundatora związanego z kultem św. Wojciecha. W tych okolicznościach jako założyciela klasztoru można brać pod uwagę Władysława Hermana, Zbigniewa, Bolesława Krzywoustego oraz Bolesława Kędzierzawego.

${ }^{57}$ Sawicki, Conciliae, s. 15.

${ }^{58}$ L. Zygner, Kodyfikacja płocka biskupa Jakuba z Kurdwanowa z przełomu XIV i XV wieku, w: W mazowieckiej przestrzeni kulturowej. Prace ofiarowane w 80. rocznice urodzin Profesora Ryszarda Juszkiewicza, red. B. Dymek, Warszawa 2007, s. 43. 
1423. ${ }^{59} \mathrm{Z}$ uwagi na to, iż synod zwołany omawianym zarządzeniem miał być najbliższym synodem w stosunku do synodu, na którym wydany był ten przepis, należy umieścić go w najbliższym sąsiedztwie 1398 roku ${ }^{60}$ Tym samym powinno się wskazać dzień 8 listopada 1400 roku jako dzień odbycia kolejnego synodu pod przewodnictwem administratora i duszpasterza biskupstwa płockiego. Niestety, nic bliższego na temat tego synodu nie jest nam wiadome, ale raczej nie wydano na nim żadnych statutów. Jednakże można pokusić się o sformułowanie wniosku, iż Jakub z Korzkwi jako odpowiedzialny rządca diecezji starał się zwoływać synody regularnie, co dwa-trzy lata.

Określenie kolejnych dat synodów odbytych pod auspicjami doktora dekretów nastręcza mnóstwo trudności. Pomocne informacje czerpiemy również z podnoszonego formularza płockiego. Otóż, 19 grudnia nieoznaczonego roku z miejscowości zaczynającej się na literę „O” napisał biskup Jakub do swojego oficjała Mroczka z Grąbca list. Przeczytać w nim możemy, iż przełożony oficjała poinformował go o przesunięciu terminu nadzwyczajnego posiedzenia kapituły z najbliższej niedzieli po dniu 19 grudnia na wtorek po synodzie. ${ }^{61} \mathrm{Z}$ uwagi na to, iż corocznie 2 lutego zbierała się kapituła generalna, to należy założyć, że czas odroczenia jej nadzwyczajnego posiedzenia musiał być krótki. ${ }^{62}$ Reasumując, wydaje się słusznym założeniem ustalenie daty kolejnego „,synodu na ostatnie dni grudnia roku napisania listu albo na pierwsze dni stycznia następnego roku"63. Następnym problemem jest określenie konkretnego roku omawianego wydarzenia. Przydatna w tym względzie okazuje się osoba adresata listu. Oficjała Mroczka wymienia dokument biskupa Jakuba z 1418 roku. ${ }^{64}$ Natomiast 5 czerwca 1419 roku występuje w źródłach oficjał płocki Jan Włodkowic zwany Różany, który w Winnicy koło Pułtuska wydał dekret w sprawie Mikołaja plebana w Okuninie. ${ }^{65}$ Świadczy to o tym, iż przed 5 czerwca 1419 roku Mroczek z Grąbca nie pełnił już urzędu oficjała. Zatem w ustalaniu daty kolejnego synodu należy wykluczyć zarówno rok 1419 , jak i 1418. Trzeba również pamiętać o nieobecności Jakuba w Korzkwi w powierzonej mu diecezji od końca 1414 roku do przynajmniej połowy 1418 roku z uwagi na reprezentowanie Polski na soborze w Konstancji. Dodatkowo trzeba podkreślić, że Mroczka z Grąbca odnajdujemy na urzędzie oficjała płockiego po raz pierwszy 3 lutego 1411 roku. ${ }^{66}$ Natomiast jeszcze 3 lutego 1407 roku w dokumentach występuje oficjał Stanisław. ${ }^{67}$ Trudno tu bezsprzecznie ustalić od kiedy po tej dacie Mroczek objął urząd oficjała płockiego. W ustaleniu spornej daty dodatkowo winno się wziąć pod uwagę mocne zaangażowanie Jakuba z Korzkwi

\footnotetext{
${ }^{59}$ S. Zachorowski, Jakób biskup płocki i jego działalność ustawodawcza i organizacyjna 13961425, Kraków 1915, s. 141.

${ }^{60}$ Sawicki, Conciliae, s. 54.

${ }^{61}$ Tamże, s. 54.

${ }^{62}$ Zachorowski, Jakób, s. 142.

${ }^{63}$ Sawicki, Conciliae, s. 55.

${ }^{64}$ Tamże, s. 55.

${ }^{65}$ Zygner, Kodyfikacja, s. 47.

${ }^{66}$ Tamże, s. 48.

${ }^{67}$ Sawicki, Conciliae, s. 55.
} 
w sprawy polsko-krzyżackie na przełomie lat 1410/11. Dnia 9 grudnia 1410 roku był jednym $z$ reprezentantów strony polsko-litewskiej podczas podpisania czterotygodniowego rozejmu z zakonem krzyżackim, następnie zapewne towarzyszył królowi, by 7 stycznia 1411 roku pojawić się w Toruniu, aby przedłużyć rozejm z państwem zakonnym. ${ }^{68}$ Biorąc powyższe pod uwagę należy zauważyć, że obowiązki państwowe mogły być przyczynami, dla których biskup postanowił przełożyć zaplanowane zebranie kapituły. Tak więc synod, o którym wspomina administrator diecezji płockiej w liście do swojego podwładnego, najprawdopodobniej musiał odbyć się w styczniu 1411 roku.

Leszek Zygner przytacza jeszcze jeden synod nieznany dotychczasowym badaczom, którego ślady można odnaleźć w niewykorzystanych dotąd aktach papieskich. ${ }^{69} \mathrm{Z}$ analizy wzmiankowanych dokumentów dowiadujemy się, że przed 31 marca 1421 roku odbył się synod płocki, na którym biskup Jakub został publicznie obrażony przez ówczesnego archidiakona Stanisława Pawłowskiego. Tajemniczy synod został najpewniej zwołany w 1420 roku i dotyczył zarówno trudnej sytuacji w diecezji, jaka zapanowała po buncie Sasina i Pawłowskiego, jak i przyjęcia uchwał synodu prowincjonalnego wieluńsko-kaliskiego z 1420 roku, co wiązało się z koniecznością częściowej nowelizacji obowiązującego prawa diecezjalnego. ${ }^{70}$ Niestety, znowu nic nie wiemy o uchwałach tego synodu. Możliwe, iż zaplanowane $\mathrm{w}$ czasie jego trwania prace ustawodawcze zostały brutalnie przerwane przez buntowników i podjęte na nowo dopiero po ostatecznej pacyfikacji, która nastąpiła w drugiej połowie 1422 roku.

Na zakończenie omawiania materii synodów płockich odbywających się do roku 1425 wypada podkreślić, iż brak źródeł na temat innych synodów niż wymienione nie znaczy, że takie nie miały miejsca. Wysoce prawdopodobne wdaje się, że Jakub z Korzkwi był duszpasterzem, który odpowiedzialnie podszedł do sprawowania rządów w powierzonej mu diecezji i przestrzegał skrupulatnie prawa prowincjonalnego. A według postanowień statutu prowincjonalnego odbytego w Kaliszu ${ }^{71}$ w 1406 roku pod przewodnictwem arcybiskupa Mikołaja Kurowskiego $^{72}$, biskupi byli zobowiązani zwoływać synody diecezjalne raz do roku z wyjątkiem lat, w których odbywały się synody prowincjonalne. ${ }^{73}$ Poza tym forum synodu diecezjalnego było doskonałym miejscem zarówno do omówienia kwestii dyscyplinarnych oraz ukarania występnych duchownych, jak i źródłem reformy lokalnego Kościoła. Biskup na synodzie występował jako pasterz, reformator oraz prawodawca. I Jakub z Korzkwi herbu Syrokomla doskonale zdawał sobie z tego sprawę.

\footnotetext{
${ }^{68}$ Zygner, Kodyfikacja, s. 48.

${ }^{69}$ Tamże, s. 49.

${ }^{70}$ Tamże.

${ }^{71}$ Jedno z najstarszych miast w Polsce pod względem lokacji na prawach miejskich położone w województwie wielkopolskim.

${ }^{72}$ Mikołaj Kurowski herbu Szreniawa (ok. 1360-1411), w latach 1395-99 biskup poznański, w latach 1399-1402 biskup włocławski, od 1402 r. arcybiskup gnieźnieński. Popierał politykę Władysława Jagiełły.

${ }^{73} \mathrm{~W}$. Abraham, $Z$ dziejów ustawodawstwa synodalnego diecezji płockiej, w: Księga pamiatkowa ku czci Oswalda Balzera, t. 1, Lwów 1925, s. 3.
} 
Dnia 26 stycznia 1423 roku wybitny kodyfikator promulgował na kapitule generalnej zbiór ustaw synodalnych dla swojej diecezji, które w przeważającej części pochodziły z wcześniejszego okresu jego rządów, a mianowicie z synodu 1398 roku i lat następnych. W 1423 roku biskup dodał do swych wcześniejszych ustaw jedynie kilka nowych dotyczących przede wszystkim spraw związanych z katedrą płocką i kapitułą katedralną. Może wydawać się niespotykane, że rewizji swoich statutów Jakub z Korzkwi dokonał nie na synodzie, ale na kapitule generalnej. Jeśli w 1423 roku nie odbył się synod, to musiały zaistnieć ku temu powody najwyższej wagi, gdyż znając skrupulatność byłego sędziego Sacra Romana Rota, można domniemywać, że synod zostałby zwołany na pewno, gdyby istniała taka możliwość. Trzeba mieć na uwadze również fakt, że był to czas niezwykle ciężki dla płockiej diecezji. Niedawno zakończyła się wojna z Krzyżakami i trudno było ściągnąć w zadowalającej liczbie duchowieństwo na synod spustoszonej diecezji. Poza tym wydaje się, że biskupowi chodziło bardziej o uzupełnienie i zmiany dawniejszego ustawodawstwa niż synod sensu stricto. ${ }^{74}$

$\mathrm{Na}$ kodyfikację płocką składają się 43 artykuły. Nie jest to jednak pomnik jednolity, a proweniencja poszczególnych przepisów jest różna. Analizując zwód Jakuba z Korzkwi od razu nasuwa się stwierdzenie, iż rozpada się on na dwie części. Pierwsza obejmuje artykuły 1-38, a druga 39-43. Opierając się na przedmowie ustaw synodalnych Stanisław Zachorowski uznał, że artykuły pierwszej części zostały zaczerpnięte ze statutów synodu diecezjalnego płockiego odprawionego 8 września 1398 roku. ${ }^{75}$ Jednakże nie można jednoznacznie stwierdzić czy nie ma w części pierwszej artykułów pochodzących z innych źródeł oraz czy statuty z 1398 roku w całości zostały dokooptowane do kodyfikacji z 1423 roku. W części drugiej zbioru znalazły się rozporządzenia biskupa wydane na kapitułach generalnych, będące częściowo nowelą, a częściowo zaś uzupełnieniem przepisów części pierwszej. ${ }^{76}$ Prace nad omawianym pomnikiem średniowiecznego ustawodawstwa kościelnego przebiegały najprawdopodobniej w trzech etapach. Najpierw zebrano w jeden zwód artykuły 1-34 tejże kodyfikacji i uporządkowano cały materiał ustawodawczy według systematyki Dekretałów. Etap ten nastąpił na samym początku XV wieku, jeszcze przed 1405 rokiem, bo już wtedy można stwierdzić istnienie w katedrze płockiej osobnej księgi ze statutami synodalnymi płockimi. ${ }^{77}$ Następnie dodano do pierwotnego zwodu cztery nowe statuty, a mianowicie artykuły 35-38, które mają charakter przepisów uzupełniających i wypadają całkowicie z systematyki Dekretałów. Ponieważ artykuł De celebracione festivitatum per totum annum (36), wskutek ogłoszenia zwodu Trąby w 1420 roku, wymagał nowelizacji i został zmieniony na mocy artykułu De celebracione festivitatum (42) w latach 1420-23, to siłą rzeczy drugi etap prac kodyfikacyjnych musiał dokonać się przed 1420 rokiem. ${ }^{78} \mathrm{Z}$ kolei trzeci etap nastąpił w 1423 roku i polegał na dodaniu pięciu nowych artykułów 39-43 oraz opublikowaniu całości

\footnotetext{
${ }^{74}$ S. Zachorowski, Studia z historii prawa kościelnego i polskiego, Kraków 1917, s. 131.

${ }^{75}$ Sawicki, Conciliae, s. 33.

76 Tamże, s. 34.

${ }^{77}$ Zygner, Kodyfikacja, s. 53.

${ }^{78}$ Tamże, s.54.
} 
jako jednolitej kodyfikacji prawa diecezjalnego. Potwierdza to końcowa formuła aktykacyjna, w której mieści się podnoszona data.

W tym miejscu konieczna się wydaje próba nadania charakteru poszczególnym artykułom. Od razu należy podkreślić, iż w kodyfikacji płockiej mamy do czynienia co najmniej z trzema odmiennymi typami ustawodawstwa synodalnego. Możemy wydzielić grupę artykułów bez wątpienia z cechami statutów synodalnych. Należą do niej: De constitucionibus (1 ust. 1 i 3), De rescriptis (2), De contumacia et dolo (17), De habitu clericorum (20), De conhabitacione clericorum et mulierum rubrica (21), De rubrica de matrimonio contra interdictum ecclesie contracto (34), De osculo pacis (35), De celebracione festivitatum per totum annum (36) oraz De modo relipipiorum circa capucia deferendorum (38). ${ }^{79} \mathrm{Kolej-}$ ną grupę tworzą artykuły zawierające obszerne rozporządzenia biskupie wydawane na kapitułach generalnych za radą i zgodą kapituły płockiej i obecnych dostojników zakonnych. Są to: De constitucionibus (1 ust. 2), De eleccione (4), Quator dies capitula generalia durare debent (5), Negocia ecclesiarum de importancia in capitulo generali tractati debent (6), De exequiis dominorum ac fraternitate (9), De vita et honestate clericorum (19), De rebus ecclesiarum non alienandis rubrica (24), De fabrica ecclesie (39), De redditibus ex villis prestimonialibus ad distribuciones convertendis (40), De celebracione festivitatum (42) oraz De matrimonium contrahentibus bannis non premissis $(43) .{ }^{80} \mathrm{~W}$ trzeciej grupie znajdują się fragmenty typowych statutów kapitulnych niewymagających zgody kapituły, a mianowicie: De secretis capituli non revelandis (7), De officio custodis (12), De officio ordinari (14), De celebracione missarum (31), a także De distribucionibus quottidianis ad alios usus non convertendis (41) ${ }^{81}$ Charakteru pozostałych przepisów nie da się ustalić.

Każdy artykuł kodyfikacji płockiej jest zredagowany w ten sam sposób. Najpierw arenga ${ }^{82}$, potem dyspozycja i wieńcząca całość sankcja karna. Odstępstw od tej reguły jest niewiele, a jeśli już są, to wynikają z tego, że w niektórych artykułach odpadły sankcje karne albo po sankcjach dodano jeszcze jakieś postanowienia. ${ }^{83}$ Należy w tym miejscu bliżej oddać charakter areng, gdyż banalnych się nie spotyka. Najczęściej przedstawione są w nich stany faktyczne charakterystyczne dla diecezji płockiej. Jest aż kilkanaście takich areng. Dany przepis ma reformować te opisane zdarzenia według konkretnej wizji prawodawcy. Notabene, takiego sposobu redagowania raczej nie spotyka się nigdzie indziej w polskim ustawodawstwie synodalnym, chociaż nieliczne wyjątki można spotkać w statutach synodów diecezji krakowskiej. ${ }^{84} \mathrm{~W}$ kodyfikacji Jakuba z Korzkwi występują również arengi, w których podana jest jakaś paremia prawna, będąca swoistym mottem do umieszczonego poniżej rozporządzenia. I wreszcie stykamy się z arengami, w których została wyrażona pewna zasada postępowania lub pewien kierunek,

\footnotetext{
${ }^{79}$ Sawicki, Conciliae, s. 48.

${ }^{80}$ Zygner, Kodyfikacja, s. 63

${ }^{81}$ Tamże, s. 63.

${ }^{82}$ Współcześnie występuje jako preambuła.

${ }^{83}$ Zachorowski, Jakób, s. 42.

${ }^{84}$ Tamże, s. 43.
} 
jaki biskup nadaje swoim rządom. Według Stanisława Zachorowskiego te rozbudowane arengi były skierowane przede wszystkim do wiejskich proboszczów, którzy nie rozumieli przepisów prawnych bez opisania konkretnych stosunków życiowych panujących w diecezji płockiej. ${ }^{85}$ Przez to styl statutów jest ciężki, rozwlekły i pozbawiony prawniczej precyzji, a zdania są bardzo długie i zawiłe. Dodatkowo brak w statutach fachowej terminologii prawniczej, a wszystko po to, aby nie obyci z prawem mogli łatwiej zrozumieć przepisy, których nakazano im przestrzegać pod groźbą sankcji karnych. Reasumując, można pokusić się o stwierdzenie, iż „notariusz brał w redaktorze górę nad ustawodawcą" ${ }^{\text {"6 }}$.

\subsection{Katalog przestępstw}

Ustawodawstwo synodalne regulowało całokształt spraw życia diecezjalnego odnoszących się zarówno do duchowieństwa, jak i do wiernych świeckich. Nie odbiega od tego kodyfikacja płocka, w której biskup Jakub z Korzkwi zamieszcza regulacje dotyczące obu grup społecznych. Poszczególne przepisy tyczą się albo samego duchowieństwa, albo jedynie ludności świeckiej, a niekiedy, wręcz należy stwierdzić, że całkiem często, normują kwestie tyczące się zarówno jednych, jak i drugich. $Z$ uwagi na to, iż zazwyczaj w życiu ludzkim przeplata się sacrum z profanum, taki stan rzeczy nie jest niczym nadzwyczajnym. Oto dokładny przegląd przestępstw, za które w diecezji płockiej można było ponieść karę, czasami niezwykle surową.

\subsubsection{W odniesieniu do duchowieństwa}

Co prawda nie szata zdobi człowieka, ale wiele może o nim powiedzieć. W średniowieczu, gdzie każdy miał wyznaczone miejsce, przywiązywano ogromną wagę do stroju. Każdy stan, ba niemalże każdą profesję, wyróżniały charakterystyczne akcenty w ubraniu, od barwy, przez nakrycie głowy, po kształt tuniki. Nie inaczej sprawa przedstawiała się w stanie duchownym. Statuty Jakuba z Korzkwi poświęcają wiele uwagi tej kwestii. Artykuł De vita et honestate clericorum rubrica (19) dotyczy głównie odpowiedniego stroju kanonickiego przy pełnieniu funkcji liturgicznych przez kler katedralny. ${ }^{87}$ Nade wszystko nie można było duchownym chodzić w stroju świeckim i to pod sankcją kary pieniężnej. Suknia klerycka, zresztą późniejsza sutanna, nie powinna mieć zbyt długich i szerokich rękawów, „które wzorem odzieży mnichów żebraczych franciszkanów i dominikanów były tak obszerne, że niekiedy wychodziło na nie więcej sukna aniżeli na całą szatę. ${ }^{" 88} \mathrm{~W}$ artykule De habitu clericorum (20) ustawodawca kontynuuje na-

${ }^{85}$ Zachorowski, Jakób, s. 44.

${ }^{86}$ Tamże, s. 44.

${ }^{87}$ Sawicki, Conciliae, s. 45.

${ }^{88} \mathrm{~J}$. Fijałek, Życie i obyczaje kleru w Polsce średniowiecznej na tle ustawodawstwa synodalnego, Kraków 1997, s. 28. 
kazy i zakazy dotyczące stroju duchowieństwa zamieszkującego diecezję płocką. Co ciekawe, podnoszony przepis jest cytowany w sprawie sądowej toczącej się 9 lipca 1466 roku w Pułtusku. Z akt procesowych rysuje się następujący stan faktyczny. ${ }^{89}$ Pleban Jan z Łopacina ${ }^{90}$ chodził w wyciętej szacie. Gdy dowiedział się o tym biskup płocki Ścibor z Gościeńczyc ${ }^{91}$, to wezwał go do Pułtuska na sąd. Kiedy duchowny znalazł się przed obliczem przełożonego, zapytano go, czy posiada statuty synodalne i co te statuty zawierają. Pleban zaprzeczył jakoby był w posiadaniu przepisów dotyczących stroju godnego duchownego, więc duszpasterz płocki wyznaczył mu termin do stawienia się do Płocka, gdzie miały być mu okazane statuty synodalne zakazujące chodzić w wyciętej sukni oraz wymierzona stosowna kara $\mathrm{w}$ oparciu o przepisy podnoszonych statutów. Bez wątpienia biskup powołuje się tu na zwód płockich statutów synodalnych, które znajdowały się już z początkiem XV wieku w katedrze płockiej w postaci osobnej księgi. ${ }^{92}$ Zarządzenia mieszczące się w artykule De modo relipipiorum circa capucia deferendorum (38) stanowią swoiste uzupełnienie norm prawnych sformułowanych we wcześniejszym De habitu clericorum (20), co raczej wyklucza, aby oba artykuły powstały jednocześnie..$^{93}$ Mamy tu zakaz noszenia broni przez duchownych, z interesującym bliższym jej określeniem. Mianowicie zakaz rozciąga się na broń zaczepną, a konkretnie na pociski (katapulty), oraz łuki i kusze. Koniecznie trzeba podkreślić, że kodyfikacja płocka jako jedyna określa bliżej rodzaj broni, której członkom kleru nie godzi się nosić. ${ }^{94} \mathrm{~W}$ treści podnoszonych przepisów znajdują się również regulacje dotyczące fryzury, jaką powinien nosić duchowny. Kodyfikacja płocka bardzo dokładnie i rzeczowo nakazuje nosić duchownym tonsurę ${ }^{95}$ tak, by uszy były odsłonięte, a także koronę ${ }^{96}$, czyli klerykę ${ }^{97}$. Innymi słowy duchowni mieli nosić wieniec krótko ostrzyżonych włosów wokoło głowy, której wierzchnia część środkowa powinna była być zgolona, jako przypomnienie pierwotnej korony św. Piotra. ${ }^{98}$

Omawiane artykuły regulowały także codzienne życie płockich duchownych. Przede wszystkim zabronione było oddawanie się zajęciom niegodnym stanu duchownego. Ustawodawca do takich czynności godzących w godność sługi Bożego zaliczył upijanie się, uczestniczenie w nieprzyzwoitych widowiskach ${ }^{99}$ oraz

${ }^{89}$ Sawicki, Conciliae, s. 38-39.

${ }^{90}$ Wieś położona w województwie mazowieckim.

${ }^{91}$ Ścibor z Gościeńczyc (zm. 1471 r.), biskup płocki od 1463 r. Po śmierci biskupa Pawła Giżyckiego został wybrany przez kapitułę na nowego rządcę diecezji. Nastąpiło to wbrew woli króla Kazimierza Jagiellończyka. Jednakże wybór ten został zatwierdzony przez papieża.

${ }^{92}$ Tamże, s. 39.

${ }^{93}$ Zygner, Kodyfikacja, s. 57.

${ }^{94}$ Fijałek, Życie i obyczaje kleru w Polsce średniowiecznej, s. 29.

${ }^{95}$ Przystrzyżenie włosów w tylnej części głowy, by odsłonić uszy. Tu należy tonsurę rozumieć jako klerykę.

${ }^{96}$ Wianuszek z przystrzyżonych włosów.

${ }^{97}$ Przystrzyżenie włosów na górnej części głowy.

${ }^{98}$ Fijałek, Życie i obyczaje kleru w Polsce średniowiecznej, s. 19.

${ }^{99}$ Zygner, Kodyfikacja, s. 75. 
zadawanie się z komediantami i kuglarzami, a także innymi osobami, które wiodą życie niegodziwe ${ }^{100}$. Co ciekawe, w celu przywrócenia klerowi sił, znużonemu codzienną pracą fizyczną i umysłową, oraz dla wspólnej zabawy w czasie uczty, dozwolone były niektóre rozrywki. Należała do nich gra w kostki, na którą statuty płockie nie nakładają żadnych kar. ${ }^{101}$ Niestety, takim samym przyzwoleniem prawodawcy nie cieszyła się gra w szachy, która została ograniczona wśród duchowieństwa świeckiego. ${ }^{102}$ Jest to tym bardziej niezrozumiałe, że gra w kości ${ }^{103}$ jest najstarszą znaną grą hazardową i za taką była uważana także w średniowieczu. Natomiast umiejętność gry w szachy ${ }^{104}$, które notabene dotarły do Polski najprawdopodobniej za czasów panowania Bolesława Krzywoustego, była uznawana za zaletę i szybko zyskała wysoką rangę na dworze monarszym. Jednakże z wolą kodyfikatora statutów płockich nie będziemy dyskutować.

Kolejną grupą artykułów dotyczących tylko i wyłącznie duchowieństwa są przepisy regulujące obowiązki względem rządcy diecezji, a także penalizujące rozmaite zachowania $\mathrm{w}$ pracy duszpasterskiej oraz administracyjnej kleru zamieszkującego biskupstwo płockie. Do przepisów tego typu należały m.in. De electione (4), De constitucionibus (1) i De celebratione missarum (31), które kolejno za ciągłą absencję na sesjach generalnych oraz za zaniedbania w sprawowaniu officium divinum i odprawianiu mszy św. konwentualnych przez kanonika hebdomariusza ${ }^{105}$ nakładały wysokie kary pieniężne. ${ }^{106}$ Dodatkowo podnoszony już De constitucionibus (1) wzywał duchowieństwo na synod diecezjalny i nakazywał mu stawić się na oznaczony dzień w komżach i stułach, ze statutami prowincjonalnymi i synodalnymi, w które każdy miał się zaopatrzyć do następnego synodu pod groźbą kar, ogłoszonych na poprzednim synodzie. ${ }^{107}$ De officio vicarii (13) zabrania proboszczom samowolnego dobierania sobie pomocników i oddaje tę sprawę w ręce biskupa. Na mocy tego przepisu proboszcz przy ustanawianiu wikariusza musiał otrzymać pozwolenie ze strony biskupa. Zanim duszpasterz biskupstwa płockiego taką zgodę miał wydać, to kandydat na wikariusza musiał być mu przedstawiony oraz poddany egzaminowi, którym kierował biskup osobiście. ${ }^{108}$ Ta regulacja zapewniała kontrolę naczelnej władzy diecezjalnej nad wikariuszami. Z kolei przepis De officio ordinarii (14) nakładał na duchownych obo-

${ }^{100}$ Fijałek, Życie i obyczaje kleru w Polsce średniowiecznej, s. 57.

${ }^{101}$ Tamże, s. 41.

102 Tamże, s. 44.

${ }^{103}$ Gra w kości znana już była w czasach pierwotnych. Najstarsze zachowane kostki pochodzą z Egiptu sprzed ok. 4000 lat. Grze tej namiętnie oddawali się cesarze rzymscy, a imperator Klaudiusz (10 r. p.n.e.-54 r. n.e.) napisał nawet podręcznik dla graczy.

${ }^{104}$ Kolebką szachów są Indie, gdzie pojawiły się w VI w. Stamtąd dotarły do Persji i w krótkim czasie zyskały sobie wielu zwolenników. Po podbiciu Persji przez Arabów szachy rozprzestrzeniły się na inne kraje. Do Europy szachy dotarły już w VIII-IX w., początkowo do Hiszpanii, Włoch i Francji, potem do Niemiec i Anglii.

${ }^{105}$ Hebdomadarz lub hebdomadariusz (od łac. hebdomada - tydzień) przewodniczy modlitwom godzin kanonicznych. Jak nazwa wskazuje, funkcja przypada co tydzień innemu kapłanowi.

${ }^{106}$ Zygner, Kodyfikacja, s. 73.

${ }^{107}$ Sawicki, Conciliae, s. 36.

${ }^{108}$ Zachorowski, Jakób, s. 37. 
wiązek asystowania przy celebrach biskupich. ${ }^{109}$ Pod groźbą surowych kar wykonywanie obowiązku rezydencji przez kanoników normuje De clericis non residentibus (23). ${ }^{110}$ Wypełnianie obowiązku rezydencji należało do codziennych powinności duchownych i przejawiało się w przebywaniu przy katedrze lub kolegiacie przez przeważającą część roku. Niestety większości sług Bożych na starym kontynencie ten jeden z podstawowych nakazów nagminnie umykał. A kler płocki nie należał tu do wyjątków. Wielce istotnej kwestii jaką jest bez wątpienia rozdawanie urzędów i beneficjów ustawodawca poświęcił artykuł De institucionibus (22). Przepis ten reguluje sposób obsadzania parafii, zastrzegając, że instytucji tej może udzielić jedynie biskup. ${ }^{111}$ Dodatkowo instytuowany duchowny zobowiązany był do złożenia przysięgi. W myśl niniejszego artykułu, powołanie to było poprzedzane postępowaniem przeprowadzanym na mocy prawa powszechnego. Nadrzędnym celem dochodzenia było wykrycie, czy ktoś inny nie rości sobie słusznych praw do danego beneficjum. ${ }^{112}$ Natomiast zakaz oddawania jakichkolwiek przedmiotów w zastaw z majątku kościelnego uregulowany jest w artykule De pignoribus (25). ${ }^{113}$

Kiedy powstawała kodyfikacja płocka, to w każdej diecezji wędrowny duchowny jako persona non grata przyrównywany był do plagi, niejednokrotnie gorszej od niektórych starotestamentowych plag egipskich. Ustawodawca statutów synodalnych unormował sytuację obcego kleru przebywającego w diecezji płockiej w artykule Clerici peregrinis (10). ${ }^{114}$ I rzeczywiście z arengi podnoszonego przepisu rysuje się niepochlebny obraz duchowieństwa nieznanej proweniencji. Kodyfikator stwierdza, że bardzo często duchowni, którzy dopuścili się w swoich diecezjach przestępstw i gorszących czynów zostają odsunięci od wykonywania czynności kapłańskich. Ze względu na ten stan rzeczy kapłani tacy najczęściej uciekają ze swoich rodzinnych stron i udają się tam, gdzie nikt nie zna ani ich samych, ani karygodnego życia, jakie wiedli. W obcych stronach świadomie dopuszczając się profanacji sprawują czynności duszpasterskie. Aby ukrócić ten proceder, powołany artykuł postanawia pod karą grzywny, że żaden duchowny diecezjalny ani zakonny, jakiegokolwiek pochodzenia i przynależności stanowej, nie może być dopuszczony do publicznej służby Bożej w żadnym kościele w diecezji, zanim nie otrzyma od biskupa płockiego, a w okresie wakansu stolicy biskupiej od kapituły albo administratora, specjalnego pozwolenia na publiczne sprawowanie czynności kapłańskich. ${ }^{115}$

Ostatnią kwestią poruszaną przez przepisy dotyczące samego duchowieństwa jest zakaz konkubinatu wśród sług Bożych. Nieprzestrzeganie celibatu w diecezji płockiej było na tyle nagminne, że już w sierpniu 1397 roku Jakub z Korzkwi był zmuszony do zdecydowanego wystąpienia przeciwko duchownym konkubinariu-

${ }^{109}$ Zygner, Kodyfikacja, s. 72.

${ }^{110}$ S. Zachorowski, Jakób, s. 52.

${ }^{111}$ Tamże, s. 51.

112 Tamże, s. 52.

113 Tamże.

${ }^{114}$ Zygner, Kodyfikacja, s. 57.

115 Tamże, s. 64-65. 
szom. Problem ten jest podnoszony w kodyfikacji płockiej w De cohabitacione clericorum et mulierum (21). Na mocy niniejszego artykułu ustawodawca zabronił trzymania w swoim domu podejrzanych kobiet oraz utrzymywania jawnie poza domem konkubin. ${ }^{116}$ Prawodawca powołuje się w tym miejscu na akt $\mathrm{z}$ sierpnia 1397 roku, który penalizował karmienie i utrzymywanie takich kobiet, zaznaczając, iż ma on nadal moc obowiązującą. Co ciekawe, przepis ten obejmuje swym zakresem wszystkich posiadających święcenia kapłańskie duchownych płockich, bez względu na to, z jakiego stanu się wywodzą i jakiego dostąpili urzędu. Mało tego, nie jest dla kodyfikatora istotne, czy ewentualny konkubinariusz będzie w posiadaniu beneficjum, czy nie. Takie niezwykle precyzyjne i nienastręczające wątpliwości zrównanie duchownych wszelkiej proweniencji $\mathrm{w}$ obliczu prawa jest precedensem co najmniej na skalę międzynarodową. Tym samym Jakub z Korzkwi dobitnie daje wyraz swojemu przekonaniu, iż wszyscy jesteśmy równi w oczach Boga. Za przekroczenie podnoszonego zakazu jeden z prałatów płockich, kantor Stanisław, poszedł trzydzieści lat później do więzienia w Pułtusku. ${ }^{117}$ W 1466 roku na ten sam artykuł powołał się biskup płocki Ścibor z Gościeńczyc, wymierzając wikariuszowi w Rzekuniu ${ }^{118}$ Maciejowi z Magnuszewa ${ }^{119}$ „,karę więzienia za konkubinat i uczęszczanie do karczem" ${ }^{20}$. Jednakże artykuł De cohabitacione clericorum et mulierum (21) był w użyciu w praktyce kurii płockiej już od początku swojego ogłoszenia w 1398 roku. Świadczy o tym chociażby fakt, że już przed 30 grudnia 1400 roku za nieprzestrzeganie celibatu scholastyk płocki Mikołaj Sówka herbu Prawda utracił swoją prałaturę. ${ }^{121}$ Warto w tym miejscu przytoczyć również sprawę z 1405 roku wniesioną przeciwko plebanowi z Pałuk ${ }^{122}$ oskarżonemu o konkubinat i inne przestępstwa. ${ }^{123} \mathrm{Na}$ sam koniec należy zaznaczyć, że archidiakoni i dziekani wiejscy, którzy po odkryciu przestępstwa świadomie tolerowali plebanów lub duchownych, a plebani wikarych, podlegali takiej samej karze, jak konkubinariusze. ${ }^{124}$

\subsection{2. Świeckich}

Wyłącznie do świeckich mieszkańców biskupstwa płockiego odnoszą się jedynie trzy kwestie. Płacenie dziesięcin, prawo patronatu oraz zawieranie małżeństw. Obowiązek dziesięciny zawsze wywoływał mnóstwo kontrowersji, ale Jakub z Korzkwi jako sumienny administrator w trosce o zabezpieczenie majątku

\footnotetext{
${ }^{116}$ Fijałek, Życie i obyczaje kleru w Polsce średniowiecznej, s. 93.

117 Tamże, s. 77.

${ }^{118}$ Wieś położona w województwie mazowieckim.

${ }^{119}$ Magnuszew (dawniej Magnuszów), wieś położona w województwie mazowieckim. W latach 1377-1869 Magnuszew posiadał prawa miejskie.

${ }^{120}$ Sawicki, Conciliae, s. 40.

${ }^{121}$ Zygner, Kodyfikacja, s. 57

${ }^{122}$ Wieś położona w województwie mazowieckim.

123 Tamże, s. 78.

${ }^{124}$ Fijałek, Życie i obyczaje kleru w Polsce średniowiecznej, s. 94.
} 
kościelnego postanowił uregulować tę kwestię w statutach synodalnych. Artykuł De consuetudine (3) nakłada na całą ludność diecezji powszechny obowiązek składania dziesięcin kościelnych. Tych, którzy w jakikolwiek sposób obowiązkowi temu uchybiliby, czy to wprost przez odmawianie zapłaty należnej sumy, czy też przez oszukańcze jej zmniejszenie poniżej należytej wysokości, miała spotkać niezwykle surowa i dotkliwa kara - ekskomunika. ${ }^{125}$

Kolejnym nadużyciem przeciwko jakiemu ustawodawca postanowił wystąpić była symonia szerząca się wśród patronów powołujących na beneficja ludzi, którzy albo opłacili od razu taką prezentę, albo zawierali układ, na mocy którego rezygnowali z różnych uprawnień i dochodów związanych z powierzonym im beneficjum. ${ }^{126}$ Szlachta mazowiecka sprawowała patronat nad przeważającą liczbą kościołów w diecezji i ten stan rzeczy wymagał zdecydowanego i ścisłego unormowania. Artykuł De patronis crimen sacrilegii committentibus (28) nakłada karę ekskomuniki na praktyki patronów, które polegały na tym, że patronowie zabierali w całości lub w części ofiary składane przez wiernych. ${ }^{127}$ Przepis ten jest skierowany nie tylko przeciwko patronom, ale również wszystkim tym, którzy w ten sposób uszczuplali normalny dochód beneficjów. Natomiast De iure patronatus (30) występuje przeciwko nadużyciom patronów, którzy przy prezencie dopuszczali się symonii. ${ }^{128} \mathrm{Na}$ podstawie powołanego artykułu wyraźnie widać, że prawodawca zamierzał w ten sposób usunać wszystkie nieprawidłowości i przestępstwa, które mogły się zdarzyć przy prezencie. Chodzi w szczególności o to, żeby patron w wyborze duchownego patrzył na jego zalety i zdolności, a nie kierował się zyskiem materialnym. Dodatkowo niniejszy przepis zabrania patronowi stawiania przeszkód w objęciu beneficjum takiemu duchownemu, którego nie po myśli patrona wyznaczył biskup. ${ }^{129}$

Do małżeństw mężczyzn i kobiet w obcych parafiach dochodziło nad wyraz często. Spowodowane było to wykorzystywaniem przez wiernych świeckich niewiedzy w odległych diecezjach dotyczących ich osoby i zawierania przez nich w obcych kościołach powtórnych małżeństw, z wyraźnym naruszeniem przeszkody trwającego węzła małżeńskiego. W czasach, kiedy przepływ informacji był bardzo wolny, dochodziło na tym tle do bardzo wielu nadużyć, które kodyfikator statutów płockich zamierzał ukrócić. Uregulowaniem sakramentu małżeństwa Jakub z Korzkwi zajął się dwukrotnie. Statut De matrimonio contra interdictum Ecclesie contracto (34) został wydany na synodzie diecezjalnym z roku 1398. Artykuł ten stanowi, iż małżeństwo osób każdego stanu, za wyjątkiem rodziny panującej, może być zawarte tylko po dwukrotnych zapowiedziach. Proboszcz mógł udzielić ślubu dopiero po upływie dwóch tygodni od ogłoszenia pierwszej zapowiedzi. Statut płocki jest pierwszym, który w sposób jasny i dokładny sformułował wiele szczegółów dotyczących tej kwestii. ${ }^{130}$ Przepis ten musiał powstać

\footnotetext{
${ }^{125}$ Zachorowski, Jakób, s. 53-54.

${ }^{126}$ Kłoczowski, Biskup, s. 114.

${ }^{127}$ Zachorowski, Jakób, s. 54.

${ }^{128}$ Tamże, s. 52.

${ }^{129}$ Tamże, s. 56.

${ }^{130}$ Zachorowski, Jakób, s. 58.
} 
przed 1406 rokiem, kiedy to szlachta zebrana na zjeździe w Piotrkowie ${ }^{131} \mathrm{w}$ swoich uchwałach zwróciła się przeciwko dwutygodniowej zwłoce, spowodowanej powszechnym obowiązkiem głoszenia zapowiedzi małżeńskich i surową praktyką, jaka panowała w diecezji płockiej. ${ }^{132}$ Zredagowany na kapitule generalnej w 1423 roku artykuł De matrimonium contahentibus bannis non premissis (43) dotyka tego samego problemu, którym się zajmował Rubrica de matrimonio contra interdictum ecclesie contracto (34). Późniejsza zmiana dotyczy terminu, jaki ma upłynąć między pierwszą zapowiedzią a chwilą ślubu. W myśl rozporządzenia z roku 1423 ślub mógł nastąpić zaraz po ogłoszeniu drugiej zapowiedzi, czyli osiem dni po pierwszej. ${ }^{133}$ Arenga wyjaśnia, z jakich względów biskup zgodził się na tę zmianę. Dowiadujemy się, iż wiernym nie odpowiadało dawniejsze rozporządzenie w tym względzie. Mało tego, było powodem zgorszeń i wykroczeń. Z całym przekonaniem można stwierdzić, iż rządca diecezji płockiej uległ presji stanu szlacheckiego, który domagał się dla swoich małżeństw dyspensy od obowiązku zapowiedzi, a przeciwko statutowi z 1398 rok podniósł formalny protest w uchwałach konfederacji piotrkowskiej w roku 1406. Tak więc De matrimonium contahentibus bannis non premissis (43) jest swoistą nowelą do statutu Rubrica de matrimonio contra interdictum ecclesie contracto (34).

\subsubsection{Inne}

Na plan pierwszy spośród przepisów odnoszących się zarówno do kleru, jak i świeckich, wysuwają się przepisy ogólnej natury prawnej. Artykuł De rescriptis (2) nakazuje poddawanie się rozporządzeniom, mandatom i wyrokom biskupim pod groźbą surowych kar. ${ }^{134}$ De contumacia et dolo (17) reguluje sposób pozywania przed sąd biskupi oraz doręczania pozwów wśród trudnych i niezwykłych warunków. ${ }^{135} \mathrm{Na}$ mocy statutu De officio archidiaconi (11) archidiakon utracił olbrzymią część swojej jurysdykcji i to tej najważniejszej, bo dotyczącej spraw małżeńskich i karnych. ${ }^{136}$ Jest to rzecz zupełnie nowatorska i próżno szukać takiego rozwiązania w innych diecezjach przed kodyfikacją płocką. Miało to eliminować nadużycia w sądownictwie. Było to także niezwykle istotne dla wszystkich mieszkańców biskupstwa, którzy odtąd mieli być sądzeni przede wszystkim przez ordynariusza.

W artykule De parochiis (29) ustawodawca umieścił zasadę przymusu parafialnego, czyli obowiązek uczęszczania we własnej parafii na msze niedzielne,

${ }^{131}$ Piotrków Trybunalski, miasto w województwie łódzkim. Miejsce częstych zjazdów szlacheckich, następnie sejmów, z których pierwszy odbył się w 1493 r., od 1578 r. siedziba Trybunału Koronnego dla Wielkopolski.

${ }^{132}$ Sawicki, Conciliae, s. 41.

${ }^{133}$ Zachorowski, Studia, s. 130.

134 Tenże, Jakób, s. 47.

${ }^{135}$ Tamże, s. 51-52.

${ }^{136}$ Tamże, s. 48. 
spowiadania się i przyjmowania sakramentów tylko u własnego plebana. ${ }^{137}$ Tym samym przepis ten zakazywał udzielania sakramentów obcym parafianom. Świeccy bardzo często dobrowolnie zmieniali przynależność parafialną i przyjmowali sakramenty z rąk obcych duchownych. ${ }^{138}$ Zakaz ten obejmował nawet dopuszczanie osób spoza parafii, a niemających na to specjalnego zezwolenia samego biskupa bądź rektora własnego kościoła parafialnego, do nabożeństw. Omawiany artykuł jako wyjątek uzasadniający jego niestosowanie dopuszcza przypadek niebezpieczeństwa śmierci, ${ }^{139}$ który klasyfikuje jako wyjątkową konieczność.

Kolejne dwa zarządzenia regulują ewentualną możliwość nakładania się na siebie spraw ludności świeckiej i duchowieństwa. Pierwsze z nich to statut $D e$ maioritate et obediencia (16), który składa się z dwóch części nieoddzielonych formalnie. Pierwsza zabrania duchownym pełnić obowiązki kapelanów panów świeckich, dopóki nie złożą na ręce biskupa przysięgi wzmocnionej przyrzeczeniem, że wiernie dochowają praw kościelnych i rozporządzeń oraz, że zawsze będą podawali do wiadomości swych panów wszystkie postanowienia rządcy diecezji. ${ }^{140}$ Natomiast część druga ogłasza rozporządzenie odprawiania modłów za wymienionych imiennie książąt mazowieckich. Artykuł De fideiussoribus (26) zabrania duchownym przyjmowania roli ręczycieli, a zatem mieszania się do spraw świeckich. ${ }^{141}$ Zakaz obejmowania roli poręczyciela rozciągnięty jest na cały kler, któremu nie wolno było odtąd ręczyć za kogokolwiek. Jednakże prawodawca dopuszcza pewne warunki uchylające zakaz poręki. Dotyczą one jedynie członków kapituły, której przedstawiciele, zwłaszcza prokuratorowie, musieli dosyć często zawierać rozmaite umowy w jej imieniu i tym samym „mieszać się w sprawy światowe"142.

W artykule De sepulturis (27) ustawodawca podkreśla nadużycia zdarzające się z chęci zysku zarówno duchownych, jak i spadkobierców, a polegające z jednej strony na tym, że duchowni często grzebią obcych ludzi, którzy w ich parafiach wcale nie wybrali sobie miejsca wiecznego spoczynku, a z drugiej zaś, że duchowni nawet swoich parafian zgadzają się grzebać tylko za otrzymaniem pewnej opłaty, przez co dopuszczają się zbrodni symonii. ${ }^{143} \mathrm{Na}$ mocy podnoszonego statutu zabrania się duchownym świeckim i zakonnym, a także kolegiom oraz konwentom, udzielania sepultury parafianom obcym oraz osobom, którym prawo kościelne odmawia religijnego pogrzebu, ${ }^{144}$ a w szczególności ekskomunikowanym, heretykom i jawnym lichwiarzom. Równocześnie zabrania się targowania o opłaty za pogrzeby i pozwala przyjmować jedynie to, co dobrowolnie zostanie ofiarowane. Dopominać się można było tylko i wyłącznie zwrotu rzeczywiście

\footnotetext{
${ }^{137}$ Tamże, s. 52.

${ }^{138}$ Kłoczowski, Biskup, s. 116.

${ }^{139}$ Tamże, s. 117.

${ }^{140}$ Zachorowski, Jakób, s. 50.

${ }^{141}$ Tamże, s. 51.

142 Tamże, s. 29.

${ }^{143}$ Tamże.

${ }^{144}$ Tamże, s. 30.
} 
wyłożonych kosztów oraz tego, czego dozwala duchownemu domagać się zwyczaj miejscowy. ${ }^{145}$

Statut De distrahentibus bona moriencium clericorum (15) jest recepcją konstytucji papieskiej, która ma bronić nietykalności mienia pozostałego po śmierci duchownych. Podnoszona regulacja zwraca się przeciwko tym duchownym i świeckim, którzy zajmują nieruchome mienie kościelne albo rozszerzają granice swych posiadłości kosztem dóbr kościelnych. Przestępcy ci podpadają karom ustanowionym zarówno przez kościelne prawo powszechne, jak i polskie. Jednakże prawodawca podnosi karę, jaką wymierzono by im na podstawie wymienionych praw i duchowni z diecezji płockiej mają być pozbawieni beneficjów i dostojeństw kościelnych, jeśliby od dnia monicji ${ }^{146} \mathrm{~W}$ ciągu miesiąca nie zaprzestali nadużyć oraz nie wynagrodzili szkód. Jeśli wynagrodzenie nie nastąpiłoby do dwóch miesięcy, to karą miała być również niezdolność do otrzymania jakiegokolwiek urzędu kościelnego. ${ }^{147}$

\subsection{Sankcje karne}

Na wstępie trzeba podkreślić, iż statuty płockie są jedynym pomnikiem polskiego średniowiecznego ustawodawstwa synodalnego, który tak ogromną wagę przywiązuje do sankcji karnych. Od razu narzuca się spostrzeżenie, że aparat środków karnych zastosowanych w omawianej kodyfikacji jest niezwykle bogaty, a w szczególności ten dotykający duchowieństwo. Mamy do czynienia z karami pieniężnymi, więzieniem, odebraniem dochodów z beneficjum, suspensą ${ }^{148}$, pozbawieniem beneficjum, odebraniem zdolności do otrzymania beneficjum i wreszcie ekskomuniką. Skutki ekskomuniki były straszliwe. Osoba ekskomunikowana była wyłączona ze społeczności chrześcijańskiej i wracała na jej łono dopiero po uzyskaniu absolucji ${ }^{149}$, o którą nie było łatwo. ${ }^{150}$ Zresztą temu, kto przez jeden rok zostawał pod ekskomuniką i nie pogodził się z Kościołem, na wezwanie wyklinającego go biskupa konfiskowano cały majątek. ${ }^{151}$ Prawie bez wyjątku kary są ściśle i dokładnie oznaczone, a na postanowienie, iż w danym wypadku biskup arbi-

${ }^{145}$ Tamże, s. 30.

${ }^{146}$ Upomnienie.

${ }^{147}$ Zachorowski, Jakób, s. 22-23.

${ }^{148}$ Suspensa (łac. zawieszenie), kara kościelna stosowana tylko wobec duchownych, polegająca na zakazie lub ograniczeniu suspendowanym kapłanom możliwości pełnienia przez nich czynności im przynależnych z racji stanu, tj. wykonywanie jurysdykcji, nauczanie, podejmowanie aktów władzy, pobieranie dochodów.

${ }^{149}$ Absolucja (z łac. absolutio), uwolnienie, uniewinnienie. Zespół rytów i formuł towarzyszących udzielaniu sakramentów, zwłaszcza sakramentu pokuty (rozgrzeszenie), stosowany też przy uwalnianiu od cenzur kościelnych (ekskomunika, interdykt, suspensa) i przyjmowaniu do wspólnoty kościelnej grzeszników.

${ }^{150}$ R. Hube, Prawo polskie w wieku trzynastym. Pisma, Warszawa 1874, s. 169.

${ }^{151}$ Na przykład w połowie XIII w. arcybiskup gnieźnieński Jan Pełka po próżnym zastosowaniu ekskomuniki wobec niejakiego Wita, wezwał księcia łęczyckiego Kazimierza do skonfiskowania całego jego majątku tak ruchomego, jak i nieruchomego. 
tralnie orzeknie karę bardzo rzadko można się natknąć. ${ }^{152}$ Oto kilka przykładów wzmiankowanych kar. Za dopuszczenie obcego duchownego do sprawowania czynności kapłańskich bez wymaganej zgody biskupa statut De clericis peregrinis (10) nakładał karę pieniężną. Artykuł De officio vicarii (13) pozbawiał na rok dochodów z beneficjum proboszczów, którzy ustanawiali wikariusza bez zgody biskupa. Natomiast karę pozbawienia duchownych zdolności do prawnego otrzymania beneficjum nakładał przepis De maioritate et obediencia (16).

Niezwykle interesujący jest fakt, iż środki karne zawarte w omawianym pomniku są grupowane i stopniowane w celu coraz surowszego wymiaru kary. Można wręcz stwierdzić, że ustawodawca zastosował w swojej regulacji swoistą kwalifikację kar. Najpierw bowiem mamy do czynienia $z$ karą podstawową, a następnie z karą surowszą dla opornego recydywisty. Jednakże kodyfikator na tym nie poprzestaje i wykazując się niecodzienną przenikliwością oraz znajomością ludzkiej natury założył, że poprzednie sankcje karne mogłyby nie przynieść zamierzonego efektu, a adresat statutu mógłby dołączyć do grona uporczywych multirecydywistów. Aby temu zapobiec, prawodawca ustanowił więc trzecią i zarazem najsurowszą karę. Te stopniowanie sankcji karnych przede wszystkim miało na celu złamanie przestępcy i poprawienie jego zachowania. W tym miejscu wydaje się koniecznością zaprezentowanie wybranych przykładów.

Na mocy artykułu De clericis non residentibus (23) niewypełniający obowiązku rezydencji duchowny miał być karany zabraniem beneficjum na sześć miesięcy. Jeśli pod wpływem wymierzonej kary nie rozpocząłby normalnej rezydencji, to miał utracić powierzone mu beneficjum. Taka sama kara miała spotkać opornego sługę Bożego, jeżeli nie wypełniając obowiązku rezydencji bezprawnie pobierałby dochody z beneficjum. ${ }^{153}$ De electione (4), De constitucionibus (1) i De celebratione missarum (31) nakładały na przestępców kary pieniężne. Za uchylanie się od ich zapłacenia niniejsze statuty przewidywały kolejne grzywny, rzecz jasna, tym razem wyższe. Za uporczywe trwanie w przestępstwie oraz nie poddanie się dobrowolnie nałożonym karom groziła sankcja ostateczna w postaci pozbawienia godności lub kanonii. ${ }^{154}$ Również przepis De clericis peregrinis (10) ustanawiał trójstopniową karę, a mianowicie grzywnę, w dalszej części pozbawienie beneficjum oraz ostatecznie ekskomunikę.

$\mathrm{Na}$ sam koniec warto zatrzymać się nad losem duchownych konkubinariuszy. Statut De cohabitacione clericorum et mulierum (21) stanowił, że duchowny beneficjant, jeśli w ciągu ośmiu dni od ogłoszenia omawianego artykułu konkubiny albo podejrzanej kobiety nie odprawi lub odprawioną, względnie inną, przyjmie, zostanie pozbawiony beneficjum, które posiada. ${ }^{155}$ Jednakże, jeżeli przestępstwa dopuści się duchowny nieposiadający beneficjum, to ma być suspendowany od wykonywania święceń na czas określony lub na zawsze według uznania biskupa.

\footnotetext{
152 Zachorowski, Jakób, s. 63.

153 Tamże, s. 65.

154 Zygner, Kodyfikacja, s. 73.

${ }^{155}$ Fijałek, Życie i obyczaje kleru w Polsce średniowiecznej, s. 93.
} 
Jeżeli wzmiankowane kary nie przyniosą zamierzonego efektu, to opornego sługę Bożego należy ukarać więzieniem oraz 16 groszami ${ }^{156}$ praskimi. ${ }^{157}$

Ze względu na swoją obszerność oraz duży zakres spraw przez siebie objęty, a także ze względu na szczegółowe i niezwykle staranne opracowanie każdego postanowienia, kodyfikacja płocka jest nieocenionym źródłem średniowiecznego karnego prawa kościelnego. Natomiast w osobie Jakuba z Korzkwi pozwala ona widzieć nie tylko wybitnego prawnika otwartego na ówczesne nurty reformatorskie, ale również autentycznego duszpasterza odznaczającego się wyczuciem pastoralnym problemów Kościoła tamtej epoki. Tym bardziej za tymi spostrzeżeniami przemawia fakt, że aż do recepcji postanowień soboru trydenckiego statuty synodalne biskupa płockiego stanowiły najważniejszy zbiór praw, na mocy którego regulowano życie zarówno świeckich wiernych, jak i ogółu duchowieństwa zamieszkującego dzielnicę mazowiecką.

\title{
CRIMINAL LAW IN PLOCK CODIFICATION DONE BY BISHOP OF PLOCK JAKUB FROM KORZKIEW (1396-1425)
}

\begin{abstract}
Summary
This article presents the person of Bishop of Plock Jakub from Korzkiew, the arms-bearing Syrokomla, a distinguished author of Plock codification. It shows his work in the Roman Curia, the service for his country, the relationship with the Teutonic Order, his characteristics as an administrator and pastor of the diocese entrusted to him. Then the author focuses entirely on the synodical statutes of Plock announced on January 26, 1423 by Jakub. The synods which are discussed refer to the bishopric, the stages of establishing the Plock Code and the characteristic of the particular regulations. The whole text is crowned by a presentation of various punitive measures adopted by the legislator in this classic of Polish medieval canon law.
\end{abstract}

Translated by Aneta Kiper

${ }^{156}$ Za wybrany asortyment w wieku XIV i XV płacono w Polsce następujące ceny: za buty chłopskie 4 grosze, barana 8 groszy, łuk 8 groszy, kuszę 60-120 groszy, pełną zbroję płytową 475 groszy, kurę 1 grosz, pół beczułki piwa 8 groszy.

${ }^{157}$ Tamże, s. 94. 